\title{
Using a Civil Judicial Collateral Estoppel as a Means of Self-Defense for Entrepreneurs in Administrative Tax Disputes
}

\author{
Leonid Belkin, Yuriy Pyvovar, Julia Iurynets, Mark Belkin
}

\begin{abstract}
In an environment where governments require more and more money to fulfill social obligations, and the business opportunity to pay taxes is decreasing, there are dangers of pressure from the authorities on business entities to increase payments. Therefore, the current state of relations between enterprises and the state is characterized by an increased level of state intervention in the affairs of enterprises, including control over their activities. This requires the development of protective preventive mechanisms in economic activity, which should be aimed at resolving issues of protecting the rights of business entities in relations with state bodies and preventing violations of these rights. The paper aims to clarify the develop protective preventive mechanisms in economic activity, which will be based on using a civil (economic) judicial collateral estoppel. Tasks of the study: a) determine the strategies, methods and techniques for the use of favorable court practice; b) to prepare recommendations on the use of favorable court practice. The methodic of research is based on the systematization of approaches to the consideration of tax disputes in courts, of ways and methods of effective use of favorable court practice for the implementation of protective preventive mechanisms in economic activity. When doing work studied and summarized Decisions of European Court of Human Rights, 3000 decisions of Ukrainian courts, and the authors' own court practice. The research results it developed a methodology allowing to provide of effective use of favorable civil (economic) judicial practice for the implementation of protective and preventive mechanisms in the economic activities of taxpayers to prevent and decide tax disputes. The widespread use of these measures by entrepreneurs will ensure the formation of judicial practice in civil (economic) courts, which would confirm the legality of deals and, accordingly, their protection from modification in the interest of greater taxation, which would make it possible to show evidence of such legality of deals in administrative courts.
\end{abstract}

Keywords : Administrative Justice, Civil Justice, Collateral Estoppel, Self-Defense, Tax Dispute.

\section{INTRODUCTION}

$\mathrm{T}_{1}$ his is an International reputed journal that published research articles globally. Although the article is written mainly on the materials of the judicial practice of Ukraine, it

Revised Manuscript Received on September 22, 2019

* Correspondence Author

Leonid Belkin, Self-employed person, Kyiv, Ukraine. Email belkinleonid@ukr.net

Yuriy Pyvovar *, Department of Constitutional and Administrative Law, National Aviation University, Kyiv, Ukraine. Email: pyvovaryi@gmail.com

Julia Iurynets, Department of Constitutional and Administrative Law, National Aviation University, Kyiv, Ukraine. Email: iurynetsjulia@ukr.net

Mark Belkin, Law Company «Maurice Group», Kyiv, Ukraine. Email advokat@etalon.co.ua is relevant for many developed countries, in particular, the European Union (EU) countries and Russia, where the main taxes are value added tax (VAT) and income tax. Thus, in par. 20 of the decision of European Court of Human Rights (ECHR) in the case of «"BULVES" AD v. BULGARIA» stated: «The VAT Act came into force on 1 January 1999. Although at the time Bulgaria was not a member of the EU, domestic VAT legislation in many respects followed the provisions of Council Directive 77/388/EEC of 17 May 1977 on the harmonization of the laws of the Member States relating to turnover taxes, known as the Sixth VAT Directive, which at the time was the principal basis for the system of value-added tax in the EU» [3].

To the extent that this conformity applies to Bulgaria, this also applies to Ukraine.

At the same time, the calculation of these taxes (VAT and income tax) is highly dependent on the tax modification of deal. For example, in par. 32 of the decision of European Court of Human Rights (ECHR) in the case of «"BULVES" AD v. BULGARIA» stated: «By contrast, where it is ascertained, having regard to objective factors, that the supply is to a taxable person who knew or should have known that, by his purchase, he was participating in a transaction connected with fraudulent evasion of value added tax, it is for the national court to refuse that taxable person entitlement to the right to deduct» [3].

Recently, in the EU, the feeling of relatively significant VAT shortfalls is growing. For example, according to the Report «VAT Gap», EU countries lost an estimated total of $€ 152$ billion in Value-Added Tax (VAT) revenues in 2015 , according to a new study by the European Commission [8].

This raises reasonable concerns about increasing pressure on entrepreneurs to change the tax assessment of the deal.

So, S. Sergeev notes that in order to counteract an unfounded application of deducting the input VAT by unscrupulous taxpayers, the tax authorities intend to limit the receipt of tax benefits when performing taxable VAT operations. This restriction is carried out by collecting arrears not from the seller due to the widespread cases of his lack of sufficient assets, as well as information about controlling persons, but from the buyer of goods, works or services, receiving the right to reduce his tax base. However, a taxpayer claiming a tax deduction on goods or services purchased may not always be aware of his counterparty not paying taxes, that is, responsibility for the actions of an unscrupulous seller may be imputed to the taxpayer by tax authorities regardless of his fault. The author notes that the peculiarity of the German law is the presumption about the knowledge or necessity of the taxpayer's knowledge of 
non-payment of tax by his counterparty when the transaction price is below the market level or deviating from the prices of the same taxpayer for the goods sold by him [7].

This raises the question of the legal protection of deals.

Valdemaras Makutenas, Danutė Krikštonaitienè note that businesses identify tax optimization issues: imperfect and often changing tax laws, fears and mistakes in tax legislation, ignorance of tax optimization techniques and methods, unfavorable tax payment deadlines, unfavorable political environment and human factor [5].

Evaluating Ukrainian tax relations, experts note that the fiscal service continues to distort tax legislation for business [6].

Ukrainian lawyer I. Golovan emphasized that protecting the rights and legitimate interests of business entities includes activating the legal actions of the entity itself in the fight against violations of the law and the most complete use of the legislative framework to protect their rights and interests [4]. Consequently, the issue of the protection of business entities in economic and managerial relations is relevant.

A reliable solution to the issues of the safety of business entities is aggravated by the propensity of administrative courts, which resolve legal disputes with the subjects of power, with the slightest opportunity to make decisions in favor of the authorities. And this «tradition» is also inherent not only in Ukraine. Thus, in the case of «Janezevik v. Sweden» and «"Västberga Taxi Aktiebolag" and Vulic v. Sweden», the ECHR noted that «in such cases, when dealing with the question of the proper balance of interests, the Court tends to the side of the state». Consequently, preventive (preceding the practical occurrence of dangers) the use of security measures is relevant to any democratic system. These methods were developed, in particular, in the monograph by Leonid Belkin [1] and in the article by Mark Belkin [2]. At the same time, the possibility of using private law methods for the next defense of rights in public relations is put into the forefront. This article summarizes these developments.

The purpose of this paper - to develop protective preventive mechanisms in economic activity, which will be based on using a civil (economic) judicial collateral estoppel. Tasks of the study: a) determine the strategies, methods and techniques for the use of favorable court practice; b) to prepare recommendations on the use of favorable court practice.

The object of the research are methods of preventive business protection in the tax field.

\section{A. Methodology/Materials}

Sub Heading (if any) The methodic of research is based on the systematization of approaches to the consideration of tax disputes in courts, of ways and methods of effective use of favorable court practice for the implementation of protective preventive mechanisms in economic activity.

When doing work studied and summarized: Decision of European Court of Human Rights (ECHR) in the case of «"BULVES" AD v. BULGARIA»; Judgment of 12 January 2006 of the Court of Justice of the European Union in joined cases C-354/03, C355/03 and C-484/03, Optigen Ltd (C-354/03), Fulcrum Electronics Ltd (C-355/03) and Bond House Systems Ltd (C-484/03) v. Commissioners of Customs \& Excise: reference for a preliminary ruling from the High Court of Justice (England \& Wales), Chancery Division -
United Kingdom, European Court Reports (ECR) 2006, page I-00483, the CJEC; Judgment of 6 July 2006 in joined Cases C-439/04 and C-440/04, Axel Kittel v Belgian State (C-439/04) and Belgian State v. Recolta Recycling SPRL (C-440/04) (ECR 2006, page I-06161); 3.000 court decisions of Ukrainian courts, the authors' own court practice.

\section{RESULTS AND FINDINGS}

One of the peculiarities of public-legal relations is that they may arise on the initiative of any of the parties, with the consent or desire of the other party not binding. At the same time, private law subjects are under administrative and legal influence, even without direct contact with the authorities, because they must perform their public duty (tax payment, filing reports, registration, etc.). Consequently, in such circumstances, private law subjects must, with due observance of the relevant public law, provide for the independent protection of their interests.

Part 1 of Art. 19 of the Civil Code of Ukraine (hereinafter - the CC), self-defense is the use of a person to counteract violations of his right, which are not prohibited by law and do not contradict the moral principles of society.

Consider the methods proposed by the authors for self-defense of the rights of economic entities in business and management relations by creating favorable judicial practice in economic (civil) courts.

In some cases, tax authorities and administrative courts question the actual performance of commercial contracts and, on this basis, insist on adjusting the tax obligations of participants in a civil law agreement. Consequently, there is a need for more effective means of protecting contracts. One such means is the creation of the validity of contracts of judicial precedent in courts of another specialization economic or civil.

The essence of the method of economic (civilian) collateral estoppel is that, in circumstances where state bodies arbitrarily recognize invalid, fictitious, worthless, etc., any contracts at their discretion, and administrative courts do not object to it, should be in advance (although this is sometimes possible and in period of verification) to recognize as a valid contract or to recognize the fact of delivery of goods in court in the economic or (at least) the general court. The advantage of this approach is, first, a more careful attitude of the economic courts system evidence unlawful transaction. For example, economic courts know precisely the difference between a void transaction and a fictitious (controversial) transaction, as opposed to how administrative courts sometimes do this, perhaps in direct agreement with the authorities. Thus, in the Resolution District Administrative Court (DAC) m. Kyiv from 15 Oct. 2013. In the case No 826/14108/13-a decision upheld by the Kyiv Appeal Administrative Court (KAAC) from 16 Jan. 2014, decided on collection in accordance with the scheme of Part 3 of Art. 228 of the CC: with Ltd-1 in favor of Ltd-2 the cost of works performed in the amount of UAH 7208000, paid under the contract from 30 Aug. 2012 No 1/8/12 and collected from Ltd-2 in the state's income UAH 7208000 at the same time, the contract was not invalidated by court. In the court ruling, he was called «insignificant», but the court avoids a reference to a specific part of Article 228 of the CC. However, in Part 3 of Art. 228 of the CC states: «if the 
court declared invalid an act was committed for the purpose...», that is, for the application of sanctions, which are supported by the court, there should be the conditions specified in Part 3 of Art. 228 of the CC, but under this norm the contract is disputed. Court to the transaction, directly named in Part 3 of Art. 228 the CC disputed, applying the rules established for a void transaction, mixing these concepts into a heap.

The said court decisions were repealed by the SAC Resolution dated 17 Apr. 2014 No K/800/6015/14. But before the adoption of this resolution, the authorities have already managed to recover from Ltd-2 in the state's income of UAH 7208000.

Second, and perhaps more significant advantage, is that, formally considering purely economic relations, economic courts do not interfere in budgetary relations and do not «solve» the question of filling the budget. And already administrative courts, which, in the understanding of the authorities, «responsible» for filling the budget, are simply forced to reckon with the decisions of the economic (general) courts, since the circumstances established by a judicial decision in an administrative, civil or economic case that came to legal effect, are not subject to repeated evidence in the consideration of other cases in which the same persons or the person to whom these circumstances are established take part.

That is, there is a diversification of risks for judges of different courts to be called «enemy of the budget».

At the same time, according to the Ukrainian legislation, direct recognition of the contract as a valid or direct determination of the fact of delivery of goods to the buyer in the Ukrainian economic legal process is impossible. But it is possible on a case-by-case basis to develop and implement certain legal constructions that would allow the desired goal to be achieved.

For example, the execution of an act of execution of a contract may be foreseen not only in contracts of performance of works or services, but also in contracts of sale of goods (deliveries) of goods. For example, one party does not fulfill such a condition, and the other party addresses the economic court with an action on the obligation to issue such an act. Thus, the Commercial Court of the Odessa region in the case No 8-20/17-720-2011 considered the claim of Private Enterprise PE-1 to the private enterprise PE-2 on the obligation of PE-2 to fulfill the obligations under the contract for the supply of agricultural products from 10 Oct. 2010, namely, to provide an act of receipt-transmission of the delivered goods. In a judgment dated 25 Jul. 2011, the court investigated the existence of invoice invoices for the corresponding goods, invoices, and also tax invoices drawn up for the purpose of assigning the VAT mentioned in them to the tax credit. Thus, the court established the existence of the fact of delivery of goods, therefore obliged the defendant to provide an act of receipt-transfer of goods delivered. The established fact of the delivery of the goods has a provisional value for consideration of a tax dispute in the event of the taxpayer's failure to recognize such a supply.

In principle, after receiving the goods, you can also sue for the requirement to put the goods (compulsory execution of the duty in kind, paragraph 5 of Part 2 of Article 16 of the CC). Then the court must investigate and establish the delivery of the goods and refuse the suit. But the fact of delivery will be established. However, the court fee for such a suit will be higher, since it will be paid from the cost of delivery.

Claims for the recognition of contracts will be dealt with more cheaply, since the sum of the court fee is paid out as from an intangible claim. Yes, according to Part. 1, 2 Art. 234 of the $\mathrm{CC}$, a fictitious transaction, committed without the intention of creating legal consequences, which was conditioned by this transaction. The fictitious transaction is declared invalid by the court. That is, if the buyer does not have a consignment note, the buyer can apply to the court with a claim on the recognition of the contract invalid as fictitious, because the delivery of the goods did not occur, that is, there are no legal consequences of the conclusion of the contract. The supplier will prove that the delivery has taken place, and the consignment note is not the only document that confirms this.

Characteristic from the point of view of the significance of judicial review, there is a case described in the decision of the SAC of 24 Jan. 2013 No K-6132/07. Thus, the Ltd was accused by the tax authorities that it did not include gross premiums as a pre-payment for the goods actually received under the contract commission for the purchase of the goods. By a decision of the Economic Court of Kirovohrad region dated 21 Feb. 2006, as a district administrative court in a lawsuit against the tax authorities regarding the interpretation of the status of payment received as a result of a commission commission was revoked. By a decision of the Dnipropetrovsk Commercial Court of Appeal from 27 Feb. 2007 as a court of appeal, the decision of the court of first instance was annulled and the tax notice was recognized as invalid. At the same time, the Court of Appeal took into account that a commercial claim was filed by the commision on the repayment of funds for which part of the transfer of goods under the contract commission was not made. By a judgment of 5 Apr. 2006, the Economic Court of Kirovograd region in case No $17 / 52$, on the claim of the defendant to the Ltd for collection, it was established that on 24 Mar. 2004 a contract was concluded between the parties, which by its legal nature is a commission agreement. In order to comply with the said agreement, the plaintiff-payer was transferred the amount, but the supply of products was only partially implemented, in connection with which the Ltd in the interests of the commister was charged with the corresponding debt. Consequently, in deciding case No17/52, the court established the fact of both the conclusion of a commission agreement and the transfer of funds under this contract, and not under the contract of sale. The said decision came into force. Therefore, the SAC has recognized the decision of the Court of Appeal as valid from 27 Feb. 2007, in view of the established judicial predued. But it is interesting to note that at the time of the consideration of the dispute in the first instance there was no such prejudicial decision, which complicated the legal status of the plaintiff.

As a result of another review, the tax service employees came to the wrong conclusion that Ltd did not have the right to sell bills of exchange on its own behalf as securities, even through a securities trader under an agreement-order, that is, in essence, he committed an act that he allegedly had no right to do. As a result, all proceeds from the sale of bills were credited as income from «other sources». By the Resolution of the DAC m. Kyiv dated 28 Jan. 2013 in the case No 2a-14070/12/2670, which was left unchanged by KAAC 
as of 4 Feb. 2014, the corresponding tax decision was canceled. At the same time, the courts indicated that by a decision of the Commercial Court of Kyiv dated 16 Aug. 2012, which was left unchanged by the resolution of the Kyiv Economic Court of Appeal from 16 Oct. 2012 in the case No 5011-64/7853-2012, the claim was denied to Ltd-1 to Ltd-2, with the participation of a securities trader, the recognition of a bill of sale purchase invalid. Claims in this case were motivated by the fact that the defendant was not entitled to conclude a disputed contract of sale of securities due to the fact that the exclusive mode of his activity is the provision of financial services and he was not entitled to carry out transactions for the sale and purchase of securities papers. Commercial courts came to the conclusion that the defendant had the right to conclude a disputed agreement with the plaintiff through a securities trader licensed to conduct brokerage. Therefore, the claims of tax service employees to the contract are false.

Of course, for the consideration of a case in an economic (civil) court, an appropriate evidence base must also be established, including taking into account the recommendations described above regarding the particularities of concluding contracts, but also with the understanding that the basis for resolving public disputes should be the rules correctly interpreted substantive contractual (economic and/or civil) law.

\section{CONCLUSION}

In an environment where governments require more and more money to fulfill social obligations, and the business opportunity to pay taxes is decreasing, there are dangers of pressure from the authorities on business entities to increase payments. Therefore, entrepreneurs are forced to resort to complex legal schemes to uphold their interests. Alternative techniques of legal technology are especially relevant for the self-defense of entrepreneurs from tax authorities in the courts of administrative jurisdiction. In particular, this applies to conflict situations when taxpayer entrepreneurs need to challenge decisions of the tax authorities in the administrative court, which (decisions) are based on assumptions regarding the recognition of economic contracts invalid, fictitious or insignificant.

Based on the procedural link between the norms of administrative, civil and commercial law, as well as the experience of judicial practice, the authors recommend to use honest taxpayers in such conflict situations, including for their prevention, to use such a legal remedy as a private judicial prejudice. Recognizing this tool as a professional result of the work of courts of a special (civil-contractual or economic-contractual) jurisdiction, it is advisable to use it in the following ways:

a) by preliminary confirmation in the civil (economic) court of the validity of the contract;

b) by preliminary recognition by a civil (economic) court of the actual fact of delivery of products, provision of services, performance of works;

c) a petition to a civil (economic) court on the enforcement of a counterparty's duty in kind;

d) recognition by the civil (economic) court the facts of conclusion the contract and transfer of funds (pay) in this particular contract.
Of course, the application of the measures proposed by the authors leads to additional costs for business, time, which sometimes can be unprofitable for them. Therefore, these ways are aimed primarily at large taxpayers, or for additional legal "insurance" of value transactions related to significant tax amounts (tax, tax reimbursement, etc.).

The listed measures will assist taxpayers in obtaining appropriate evidence in the form of decisions of a civil (economic) court for their further use in public-law disputes with tax authorities in administrative courts. The widespread use of these measures by entrepreneurs will ensure the formation of judicial practice in civil (economic) courts, which would confirm the legality of deals and, accordingly, their protection from modification in the interest of greater taxation, which would make it possible to show evidence of such legality of deals in administrative courts.

Prospects for further research in this direction are a synthesis of new, emerging protection mechanisms, as well as a synthesis of modern protection experience.

\section{ACKNOWLEDGMENT}

This article was supported in parts by Department of Constitutional and Administrative Law research work is state budget theme "Public-legal mechanism of guaranteeing Ukraine's national interests" (No. 55/13.01.02).

\section{REFERENCES}

1. L.M. Belkin, Ensuring Legality in the Activity of Executive Authorities Administrative and Legal Measure. FOP Breza, Uzhgorod, 2014.

2. M.L. Belkin, Simplification of Judicial Preludes as a Means of Protecting the Rights of Taxpayers in Administrative Proceedings. Administrative law and process, 2012, 1, pp. 96-105.

3. European Court of Human Rights (ECHR), Decision of in the Case of «"BULVES" AD v. BULGARIA». Available: http://docs.pravo.ru/document/view/19676037/

4. I.V. Golovan, Legal Work and Defense of Entrepreneurs' Rights. Yuho-Vostok, LTD, Donetsk, 2003.

5. V. Makutėnas, D. Krikštonaitienè, Modeling of Tax Optimization Opportunities in Business Enterprises. Management Theory and Studies for Rural Business and Infrastructure Development, 2017, Vol. 39 (3), pp. 303-314.

6. N. Nepryakhina, (2015, September 21). The SFS Continues to Tighten the Nuts of the Business. RBK Ukraine. Available: https://daily.rbc.ua/rus/show/gfs-prodolzhaet-zakruchivat-biznesu-nalog ovye-1442863889.html

7. S.V. Sergeyev, Kontseptsiya Dolzhnoy Osmotritelnosti v Germanskom i Rossiyskom Prave. Voprosy rossiyskogo i mezhdunarodnogo prava, 2017, Vol. 7 (2a), pp. 111-122. Available: http://publishing-vak.ru/file/archive-law-2017-2/11-sergeev.pdf

8. VAT Gap.

http://europa.eu/rapid/press-release_IP-17-3441_en.htm

\section{AUTHORS PROFILE}

Leonid Belkin, Ph.D., Self-employed person, Kyiv, Ukraine. ORCID 0000-0001-8672-8147, Scopus ID: 7004014294

Yuriy Pyvovar, Head of Department of Constitutional and Administrative Law, National Aviation University, Kyiv, Ukraine, Prof., $\mathrm{PhD}$ in Law, ORCID 0000-0001-8258-7930, Scopus ID: 57203992023, Web of Science ID: O-4973-2016

Julia Iurynets, Doctor of Law, Associate Professor, Professor of Department of Constitutional and Administrative Law, National Aviation University, Kyiv, Ukraine. ORCID: 0000-0003-0281-3251, Scopus ID: 57204003786,Web of Science ID: D-4794-2018

Mark Belkin, PhD in Law, Law Company «Maurice Group», Kyiv, Ukraine. ORCID: 0000-0003-0805-9923 